\title{
Sources of otolith barium and strontium in estuarine fish and the influence of salinity and temperature
}

\author{
S. D. Webb, S. H. Woodcock, B. M. Gillanders* \\ Southern Seas Ecology Laboratories, DX 650 418, School of Earth and Environmental Sciences, University of Adelaide, \\ South Australia 5005, Australia
}

\begin{abstract}
Otoliths are commonly used to reconstruct migratory patterns and to determine stock structure of fish, owing to the chemical relations between water and otolith chemistry. Water is only 1 source of variation in otolith chemistry, and the contribution that diet plays to the chemical composition of otoliths under different environmental influences, including temperature and salinity, has been largely unexplored. To determine the percentage contributions from water and diet to otolith Ba and Sr, juvenile Acanthopagrus butcheri (Munro 1949) (Sparidae) were reared in 3 different salinities under 3 different water temperatures. For the first time, both rearing water and diet were enriched with stable isotopes of $\mathrm{Ba}\left({ }^{137} \mathrm{Ba}\right.$ and $\left.{ }^{136} \mathrm{Ba}\right)$ and $\mathrm{Sr}\left({ }^{88} \mathrm{Sr}\right.$ and $\left.{ }^{86} \mathrm{Sr}\right)$; thus enabling us to determine contributions of water versus diet to the otolith. Ambient water was the primary contributor to otolith Ba (between 62 and $84 \%$ ) and Sr (between 59 and $84 \%$ ). Water contributions to otolith Ba were not significantly affected by temperature or salinity. A significant interactive effect of temperature and salinity on water contributions to otolith Sr was detected, which was most evident at high temperatures where contributions from the water decreased with increasing salinity. This study supports water as the primary contributor of otolith chemistry and suggests that the contribution of water can be influenced by environmental factors such as temperature and salinity.
\end{abstract}

KEY WORDS: Water · Diet · Percent contribution $\cdot$ LA-ICP-MS · Solution ICP-MS · Acanthopagrus butcheri $\cdot$ Otoliths $\cdot$ Stable isotopes

Resale or republication not permitted without written consent of the publisher

\section{INTRODUCTION}

Elemental and isotopic concentrations of calcified structures have been used to make inferences of past diets and/or environmental history of terrestrial and aquatic organisms. The most commonly used calcified structure in fish are otoliths, paired calcium carbonate $\left(\mathrm{CaCO}_{3}\right)$ structures present in all teleost fish, which assist in balance and hearing (Campana 1999); they are found within the inner ear, suspended in endolymphatic fluid and isolated by a semipermeable membrane, the endolymphatic sac (Campana \& Thorrold 2001). The chemical composition of otoliths can reflect, to some degree, the environment to which the fish are exposed throughout their life
(Campana 1999). In addition, otoliths are metabolically inert (Campana \& Thorrold 2001), which means that they are not subject to re-absorption. Elements are crystallised out of the surrounding endolymph onto the otolith edge in concentric rings (Campana \& Neilson 1985). Increments and their subsequent element concentrations can thereby provide a chemical 'journal' of a fish's life, which can then be used to determine past history (Campana 1999).

Otolith chemistry has been used for a number of applications, including reconstructions of fish migratory pathways (for example Gillanders 2005, Elsdon \& Gillanders 2006) and the determination of fish stock structure (e.g. Bergenius et al. 2005, Jónsdóttir et al. 2006). The majority of this research relies on the 
assumption that otolith chemistry is reflective of the environment in which the fish lives (Bergenius et al. 2005, Jónsdóttir et al. 2006, Elsdon et al. 2008). Concentrations of elements such as strontium ( $\mathrm{Sr}$ ) and barium (Ba), which are known to substitute for calcium (Ca) in the $\mathrm{CaCO}_{3}$ structure (Campana 1999, Bath et al. 2000), display high correlations between the environment and otoliths (Bath et al. 2000, Elsdon \& Gillanders 2003b, de Vries et al. 2005). Ambient water and diet represent the 2 known sources of otolith chemistry (Campana 1999), and incorporation of trace elements from these sources may be controlled by environmental (Elsdon \& Gillanders 2003b, Arai et al. 2004, Kraus \& Secor 2004) and physiological variables (Kalish 1989, Sadovy \& Severin 1994, Arai et al. 2003), which may affect biomineralisation of elements into the otolith.

Few studies have investigated the relative contributions of diet and water to otolith composition (but see Farrell \& Campana 1996, Kennedy et al. 2000, Walther \& Thorrold 2006, Gibson-Reinemer et al. 2009). Most conclude that water is the major contributor to otolith chemistry and that diet has little or no effect on otolith chemistry (Farrell \& Campana 1996, Walther \& Thorrold 2006, Gibson-Reinemer et al. 2009). However, Kennedy et al. (2000) suggested that $70 \%$ of Sr in Salmo salar otoliths was derived from dietary sources. Past contribution studies have examined the contribution from either water or diet only at a single salinity and temperature, and therefore were unable to report any salinity, temperature or interactive effects on source contributions. Despite this, salinity or temperature may influence contributions from each source, through impacts on osmoregulation as well as water and/or food intake.

Osmoregulation is the process of altering water potential to maintain the fluid and electrolyte balance within the fish despite changes in ambient water conditions (Lignot et al. 2000). Osmoregulation is important for both marine and freshwater fish. Marine fish require a large water intake, as water loss is high due to osmosis and the passive movement of water out of the fish into ambient water (Campana 1999, Boeuf \& Payan 2001). Freshwater fish, however, do not require a large water intake, but they need to actively uptake ions from ambient water as concentrations are lower in water compared to the fish (Perry 1997). Since marine and freshwater fish have different adaptations for osmoregulation, different amounts of elements may be available from ambient water for otolith incorporation. Therefore, estuarine fish, such as Acanthopagrus butcheri (Munro 1949) (Sparidae), which moves between fresh and marine waters, may have different amounts of elements available for uptake due to the water they reside in. This may lead to either an increase or a decrease in the relative contribution from water and the opposite trend in dietary contribution.

Dietary intake in fish increases with both water temperature (Swanson 1998, Boeuf \& Payan 2001, Imsland et al. 2001, Arjona et al. 2009) and salinity (Rubio et al. 2005). There may, however, be an upper temperature and salinity threshold for food intake, where intake declines with further increases in temperature and salinity (Imsland et al. 2001, Handeland et al. 2008, Luz et al. 2008). A change in food intake may thereby affect relative contributions to otolith chemistry since varying amounts of elements will be available for incorporation from the diet.

Relative contributions of diet and ambient water to otolith chemistry from past studies have reported varying results, and therefore the contributions of each are still relatively unknown. In addition, no studies have addressed the potential influence of changing salinity and temperature on diet versus water contributions to otolith chemistry, or enriched both the water and the diet to independently test contributions. Thus, we tested the hypotheses that (1) ambient water is the main contributor to $\mathrm{Ba}$ and $\mathrm{Sr}$ otolith chemistry, and (2) salinity and temperature will influence the percent contribution of elements into the otolith, due to changes in diet and water uptake under different environmental conditions.

\section{MATERIALS AND METHODS}

\section{Experimental design}

Juvenile Acanthopagrus butcheri, approximately 20 to $30 \mathrm{~mm}$ total length (TL), were obtained from the Challenger Training and Further Education (TAFE) hatchery, Western Australia, and held in three 2501 fibreglass tanks at a salinity of $35 \%$ and a water temperature of $16^{\circ} \mathrm{C}$. Each tank was adjusted to 1 of 3 salinities $(10,20$ and 30$)$ through $5 \%$ changes per day. After an acclimatisation period of at least $24 \mathrm{~h}$ at set salinities, fish were marked with $0.5 \%$ calcein using the osmotic induction technique described by Crook et al. (2009). Following calcein marking, fish were assigned to treatment tanks at their respective salinities, with 7 fish stocked into each tank, which were then adjusted to 1 of 3 different water temperatures $\left(16,20\right.$ and $\left.24^{\circ} \mathrm{C}\right)$ through $2^{\circ} \mathrm{C}$ changes per day.

Experimental treatments consisted of 2 replicate 151 acid- and bleach-washed plastic tanks contain- 
ing 101 of water. A small internal filter was placed in each tank (JT Filtration Pump, JHJ-411B, $300 \mathrm{l} \mathrm{h}^{-1}$ ) along with an air stone. Tanks were held in water baths to maintain desired water temperature during the experimental period, and were covered with clear plexiglass lids to minimise evaporation. All saltwater used during the experiment was delivered from the South Australian Research and Development Institute (SARDI) Aquatic Sciences division at West Beach, South Australia, and held in an outdoor storage tank, and diluted to the desired salinity using aged freshwater. Water was spiked with ${ }^{137} \mathrm{Ba}$ or ${ }^{88} \mathrm{Sr}$ by dissolving isotopically enriched $\mathrm{BaCO}_{3}$ or $\mathrm{SrCO}_{3}$ (Oak Ridge National Laboratories, Oak Ridge, Tennessee, USA) at a concentration of $0.1 \mathrm{mg} \mathrm{l}^{-1}$ for ${ }^{137} \mathrm{Ba}$ or $0.25 \mathrm{mg} \mathrm{l}^{-1}$ for ${ }^{88} \mathrm{Sr}_{\text {; }}$ enriched concentrations were based on a previous isotope marking study (Woodcock et al. 2011), and spiked at the same concentration, regardless of salinity, ensuring a constant spike volume. Enriched Ba and Sr treatments consisted of all possible combinations of water temperature (16, 20 and $24^{\circ} \mathrm{C}$ ) and salinity (10,20 and 30), referred to hereafter as low, ambient and high, respectively. Water quality was maintained through weekly $50 \%$ water changes.

Fish were fed a gelatin-based diet during the acclimatisation period based on the recipe by Royes \& Chapman (2003). Ingredients included prawns in brine (drained), frozen spinach, grated carrot, rolled oats, wheat germ and cod liver oil. During the experiment, fish were fed the same gelatin-based diet spiked with either ${ }^{136} \mathrm{Ba}$ at $0.1 \mu \mathrm{g} \mathrm{g}^{-1}$ for Ba treatments or ${ }^{86} \mathrm{Sr}$ at $0.25 \mu \mathrm{g} \mathrm{g}{ }^{-1}$ for Sr treatments (see 'Results' for baseline element concentrations). Isotopes were in a similar carbonate form as those used to enrich water. Fish were fed twice daily throughout the experiment, and any detritus remaining after 30 min was siphoned away. Fish were exposed to experimental conditions for $32 \mathrm{~d}$, after which they were euthanised through immersion in an ice slurry and immediately frozen until otolith extraction.

\section{Water and diet sampling and analysis}

Water samples were collected after each water change throughout the experimental period $(n=7)$. Each sample was collected from each tank using a $25 \mathrm{ml}$ syringe, filtered through a $0.45 \mu \mathrm{m}$ filter into acid-washed $30 \mathrm{ml}$ plastic vials, and acidified with $0.5 \mathrm{ml}$ of $65 \%$ concentrated nitric acid. Water samples were frozen until analysis, where they were diluted 1:10 with $2 \%$ nitric acid. To determine the isotope concentrations of $\mathrm{Ba}$ and $\mathrm{Sr}$ in the diets, a sample of each diet ( $\mathrm{n}=3$ lots of $5 \mathrm{~g}$ ) was oven dried at $60^{\circ} \mathrm{C}$ for $24 \mathrm{~h}$, ground using a mortar and pestle and dissolved in $0.025 \mathrm{~g} \mathrm{ml}^{-1} 65 \%$ concentrate nitric acid. Dilution was based on a pilot study done to determine the ability to measure the concentration of $\mathrm{Sr}$ and $\mathrm{Ba}$ in the diet. Samples were left to dissolve for $1 \mathrm{wk}$. Each sample was then diluted to achieve a $2 \%$ nitric acid concentration using ultrapure water, before being filtered through a $0.45 \mu \mathrm{m}$ filter for analysis.

Water and diet samples were analysed using an Agilent 7500 cs (www.agilent.com) inductively coupled-plasma mass spectrometer (ICP-MS); see Table 1 for operating parameters. Sr and Ba water samples were analysed separately using individual sets of standards. A natural multi-element stock standard was run for both Ba and Sr samples at 1, 50, 100 and $500 \mu \mathrm{g} \mathrm{l}^{-1}$. Ba standards included 2 additional standards for each isotope, ${ }^{136} \mathrm{Ba}$ and ${ }^{137} \mathrm{Ba}$ at 50 and $200 \mu \mathrm{g} \mathrm{l}^{-1}$. The Sr standards included 4 additional isotope-enriched solutions, 2 for both ${ }^{86} \mathrm{Sr}$ and ${ }^{88} \mathrm{Sr}$ at 150 and $350 \mu \mathrm{g} \mathrm{l}^{-1}$. Standards and blanks were analysed periodically throughout the session. Agilent Mass Hunter was used to collect raw data, which were calibrated against the elemental standards. Isotope counts per second were further corrected against both the elemental and isotope standards, before being used to calculate the isotope ratios of interest.

Table 1. Operating parameters on the Agilent 7500cs inductively coupled-plasma mass spectrometer (ICP-MS) used to analyse water and diet samples and the operating parameters for the New Wave Nd Yag 213 UV laser with ICP-MS used to analyse otoliths

\begin{tabular}{|ll|}
\hline Parameter & Value \\
\hline $\begin{array}{l}\text { Solution ICP-MS } \\
\text { Collision cell }\end{array}$ & $\mathrm{He}\left(5 \mathrm{ml} \mathrm{min}{ }^{-1}\right)$ \\
Cone & $\mathrm{Pt}$ \\
Integration time & $0.10 \mathrm{~s}$ with 3 replicates for each \\
& isotope $\left({ }^{43} \mathrm{Ca}^{88}{ }^{8} \mathrm{Sr}^{86} \mathrm{Sr}^{136}{ }^{13 a}{ }^{137} \mathrm{Ba}\right)$ \\
Laser & \\
Wavelength & $213 \mathrm{~nm}$ \\
Mode & $\mathrm{Q}-\mathrm{switch}$ \\
Frequency & $5 \mathrm{~Hz}$ \\
Spot size & $30 \mu \mathrm{m}$ \\
Laser power & $65 \%$ \\
Carrier gas & $\mathrm{Ar}\left(0.95 \mathrm{l} \mathrm{min}{ }^{-1}\right)$ \\
ICP-MS & \\
Optional gas & $\mathrm{He}(58 \%)$ \\
Cone & $\mathrm{Pt}{ }^{115} \mathrm{In}(50 \mathrm{~ms})$ \\
Dwell times & ${ }^{43} \mathrm{Ca}(100 \mathrm{~ms})$ \\
& ${ }^{88} \mathrm{Sr},{ }^{86} \mathrm{Sr}(200 \mathrm{~ms})$ \\
& ${ }^{136} \mathrm{Ba},{ }^{137} \mathrm{Ba}(400 \mathrm{~ms})$ \\
\hline
\end{tabular}


To calculate the Ba:Ca and $\mathrm{Sr}: \mathrm{Ca}$ ratios $\left(\mathrm{mmol} \mathrm{mol}^{-1}\right.$ ) in the water, the ${ }^{137} \mathrm{Ba}$ and ${ }^{88} \mathrm{Sr}$ isotopes were used.

\section{Otolith preparation and analysis}

One otolith from each fish was embedded in a 2-part epoxy (EpoFix resin and hardener, Struers) spiked with $40 \mathrm{ppm}$ indium, and $0.35 \mathrm{~mm}$ sections were cut using a low speed saw (Isomet low speed saw, model no. 11-1280-250, Buehler). Sections were then polished using lapping film ( $3 \mu \mathrm{m}$ grit size) before being fixed onto microscope slides using indium spiked CrystalBond 509 thermoplastic glue (see Munro et al. 2008 for additional details). Otoliths were analysed on a New Wave Nd Yag 213 nm UV laser operated in Q-switch mode connected to an Agilent 7500cs ICP-MS; see Table 1 for laser and ICP-MS operating parameters. Otoliths were analysed following methods described by Munro et al. (2008), whereby the edges of otoliths were sampled using spot analyses to ensure otolith material laid down during experimental conditions was analysed (i.e. material laid down outside the calcein mark). Ba and $\mathrm{Sr}$ isotopes $\left({ }^{137} \mathrm{Ba},{ }^{136} \mathrm{Ba},{ }^{88} \mathrm{Sr}\right.$ and $\left.{ }^{86} \mathrm{Sr}\right)$ used to enrich holding water and diet were measured along with ${ }^{43} \mathrm{Ca}$ for element:Ca ratios and ${ }^{115} \mathrm{In}$, to determine when otolith material was no longer ablated. A reference standard, NIST 612 (National Institute of Standards and Technology; www.nist.gov) was analysed throughout each session and used to correct for mass bias and machine drift (Munro et al. 2008). Data were smoothed using a 6-point running mean, and then the average value of the smoothed ${ }^{137} \mathrm{Ba}:{ }^{136} \mathrm{Ba}$ isotope ratio data and the ${ }^{88} \mathrm{Sr}{ }^{86} \mathrm{Sr}$ isotope ratio data were used as the isotopic value for each sample. To calculate the $\mathrm{Ba}: \mathrm{Ca}$ and $\mathrm{Sr}: \mathrm{Ca}$ ratios $\left(\mathrm{mmol} \mathrm{mol}{ }^{-1}\right)$, the ${ }^{137} \mathrm{Ba}$ and ${ }^{88} \mathrm{Sr}$ isotopes were used.

\section{Statistical analysis}

Statistical analyses were conducted using PRIMER 6/PERMANOVA (www.primer-e.com). Differences in the $\mathrm{Ba}$ and $\mathrm{Sr}$ ratio of water samples and otoliths were analysed individually using 3-way permutational univariate analysis of variance (ANOVA) with unrestricted permutations for both $\mathrm{Ba}: \mathrm{Ca}$ and $\mathrm{Sr}: \mathrm{Ca}$ and for isotopic ratios ${ }^{137} \mathrm{Ba}:{ }^{136} \mathrm{Ba}$ and ${ }^{88} \mathrm{Sr}:{ }^{86} \mathrm{Sr}$. Temperature and salinity were treated as fixed factors with replicate tanks treated as a random factor (nested in both temperature and salinity). Differences in the isotope ratios of the diets were tested using 1-way ANOVAs. If significant differences were detected within single or multi-factor ANOVAs, post hoc pairwise tests were used to determine which treatments or tanks differed.

\section{Percentage contributions}

The percent contributions from ambient water (Eq. 1) or diet (Eq. 2) to otolith Sr and Ba were calculated using the following equations from Kennedy et al. (2000). Calculations used log values of the isotope ratios $\left({ }^{137} \mathrm{Ba}:{ }^{136} \mathrm{Ba}\right.$ or ${ }^{88} \mathrm{Sr}:{ }^{86} \mathrm{Sr}$ ) for each factor (otolith, water and diet). To determine whether there were significant differences in the percent contribution among the different treatments, similar ANOVAs to those described above were used.

\% Element $_{(\text {water })=}$
$\left[1-\left(\frac{\log \text { isotope ratio }_{(\text {water })}-\log \text { isotope ratio }_{(\text {otolith })}}{\log \text { isotope ratio }_{(\text {water })}-\log \text { isotope ratio }_{(\text {diet })}}\right)\right] \times 100$
$\%$ Element $_{(\text {diet })}=$
$\left[1-\left(\frac{\log \text { isotope ratio }_{(\text {otolith })}-\log \text { isotope ratio }_{(\text {diet })}}{\log \text { isotope ratio }_{(\text {water })}-\log \text { isotope ratio }_{(\text {diet })}}\right)\right] \times 100$

\section{RESULTS}

\section{Rearing conditions}

Slight variations in treatment conditions for temperature and salinity were detected between replicate tanks (Tables 2 \& 3). Despite this, a significant difference was detected among temperature and salinity levels for both Ba and Sr enriched treatments (Table 3), which corresponded to differences between the set salinity and temperature treatment (Table 3) whereby temperature and salinity reflected the desired treatment levels (Table 2).

\section{Water and diet chemistry}

Water was successfully altered using enriched ${ }^{137} \mathrm{Ba}$; water had a mean $\pm \mathrm{SE}{ }^{137} \mathrm{Ba}:{ }^{136} \mathrm{Ba}$ ratio of $40.31 \pm 1.56$, compared to the natural ratio of 1.43 (Table 2). Temperature had no significant effect on the Ba:Ca ratio of the water (Table 4; Fig. 1a), although the ${ }^{137} \mathrm{Ba}:{ }^{136} \mathrm{Ba}$ ratios of the water differed (Tables $2 \& 4$ ) between the low and high temperature 


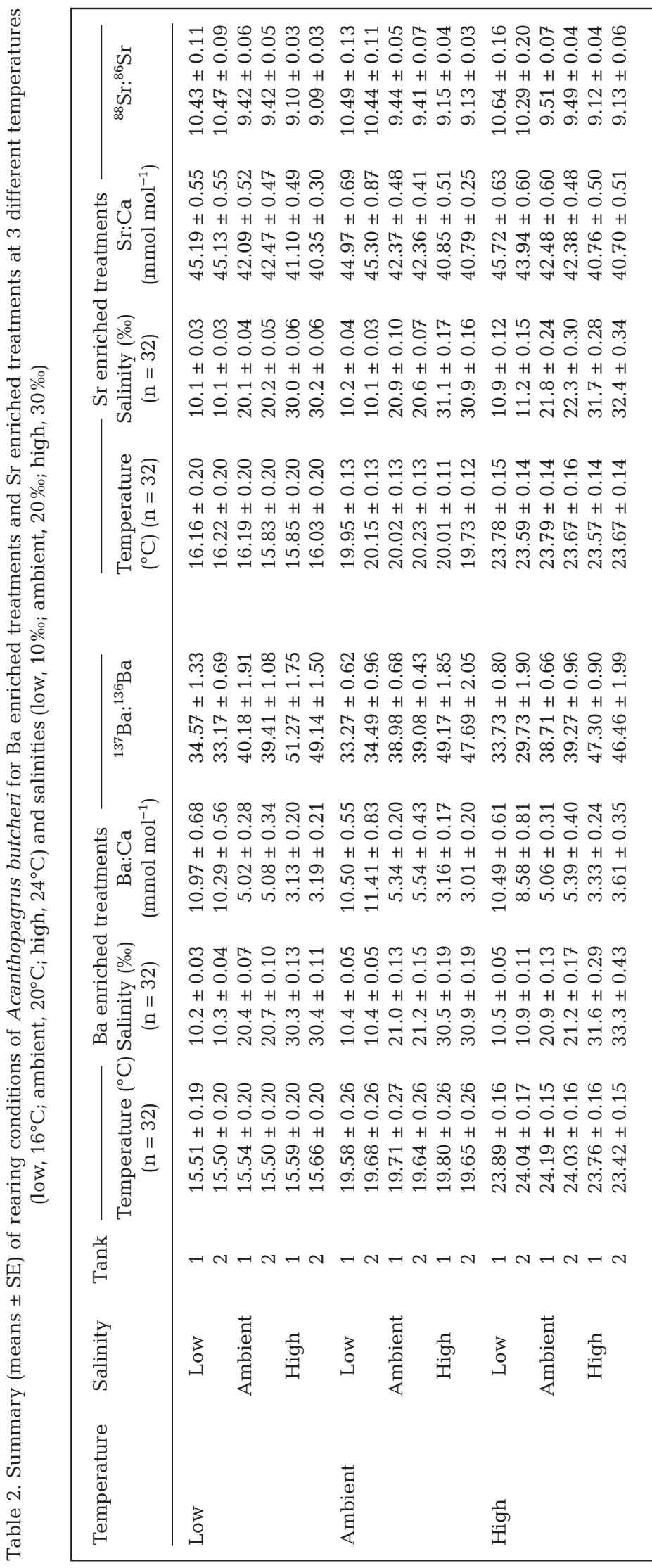

treatments. A significant difference in salinity was found across all 3 salinity treatments for both $\mathrm{Ba}$ :Ca and ${ }^{137} \mathrm{Ba}:{ }^{136} \mathrm{Ba}$ ratios (Table 4; Fig. 1a), whereby Ba:Ca concentrations decreased with increasing salinity, resulting in a larger isotopic shift in the ${ }^{137} \mathrm{Ba}:{ }^{136} \mathrm{Ba}$ ratio with increasing salinity.

Sr isotope ratios in the treatment tanks were successfully altered with ${ }^{88} \mathrm{Sr}$, and displayed a mean ${ }^{88} \mathrm{Sr}{ }^{86} \mathrm{Sr}$ ratio of $9.86 \pm 0.14$, which differed from the natural ratio of 8.38 (Table 3). Salinity was the only factor which influenced both the $\mathrm{Sr}: \mathrm{Ca}$ and ${ }^{88} \mathrm{Sr}:{ }^{86} \mathrm{Sr}$ ratios, with both ratios decreasing with an increase in salinity (Table 5, Fig. 1b).

Analysis of the non-enriched diet mixture revealed a $\mathrm{Ba}: \mathrm{Ca}$ concentration of $0.32 \pm$ $0.003 \mathrm{mmol} \mathrm{mol}^{-1}$, and a Sr:Ca concentration of $4.19 \pm 0.082 \mathrm{mmol} \mathrm{mol}^{-1}$. The enriched diets fed to Acanthopagrus butcheri were successfully altered using enriched stable isotopes. The ${ }^{136} \mathrm{Ba}$ enriched diet had a significantly reduced ${ }^{137} \mathrm{Ba}:{ }^{136} \mathrm{Ba}$ ratio compared to the nonisotope enriched and $\mathrm{Sr}$ enriched diets $\left(F_{2,12}=\right.$ $132.42, \mathrm{p} \leq 0.001)$, displaying an isotope shift from the non-enriched diet of $1.33 \pm 0.05$ to $0.66 \pm 0.02$. The ${ }^{86} \mathrm{Sr}$ enriched diet also displayed a significant difference in the ${ }^{88} \mathrm{Sr}:{ }^{86} \mathrm{Sr}$ ratio compared to the non-isotope enriched and $\mathrm{Ba}$ enriched diet $\left(F_{2,12}=86.21, \mathrm{p} \leq 0.001\right)$ with a decrease in the ${ }^{88} \mathrm{Sr}:{ }^{86} \mathrm{Sr}$ ratio from the non-enriched diets of $9.03 \pm 0.03$ to $7.99 \pm$ 0.09 .

\section{Otolith chemistry}

A significant interactive Temperature $x$ Salinity effect was found for the Ba:Ca ratios in otoliths (Table 4, Fig. 1a). Post hoc tests indicated that at ambient and high temperature, Ba:Ca ratios differed between low salinity treatments and the ambient and high salinity treatments. Post hoc tests also indicated that at high salinity, Ba:Ca differed between the high temperature treatment and both the low and ambient temperatures. Temperature and salinity had no influence on the ${ }^{137} \mathrm{Ba}$ : ${ }^{136} \mathrm{Ba}$ ratios measured in the otoliths of Acanthopagrus butcheri (Table 4, Fig. 2a). A significant tank effect was detected for otolith ${ }^{137} \mathrm{Ba}:{ }^{136} \mathrm{Ba}$ ratios (Table 4). Post hoc tests indicated variation between tanks at high 
Table 3. Analysis of variance examining measured differences in rearing conditions (temperature and salinity) among treatment tanks for Ba enriched tanks and Sr enriched tanks

\begin{tabular}{|c|c|c|c|c|}
\hline Source of variation & df & MS & $F$ & $\mathrm{p}$ \\
\hline \multicolumn{5}{|l|}{ Ba } \\
\hline \multicolumn{5}{|l|}{ Temperature } \\
\hline Temperature & 2 & 3337.10 & 9115.80 & $\leq 0.001$ \\
\hline Salinity & 2 & 0.71 & 1.94 & $>0.050$ \\
\hline Temperature $\times$ Salinity & 4 & 2.13 & 5.83 & $<0.050$ \\
\hline Tank (Temperature $\times$ Salinity) & 9 & 0.37 & 0.26 & $>0.050$ \\
\hline Residual & 558 & 1.41 & & \\
\hline \multicolumn{5}{|l|}{ Salinity } \\
\hline Temperature & 2 & 123.72 & 8.40 & $<0.050$ \\
\hline Salinity & 2 & 50325.00 & 3416.70 & $\leq 0.001$ \\
\hline Temperature $\times$ Salinity & 4 & 46.73 & 3.17 & $>0.050$ \\
\hline Tank(Temperature $\times$ Salinity) & 9 & 14.73 & 6.98 & $\leq 0.001$ \\
\hline Residual & 558 & 2.11 & & \\
\hline \multicolumn{5}{|l|}{$\mathrm{Sr}$} \\
\hline \multicolumn{5}{|l|}{ Temperature } \\
\hline Temperature & 2 & 2795.30 & 4051.80 & $\leq 0.001$ \\
\hline Salinity & 2 & 1.54 & 2.23 & $>0.050$ \\
\hline Temperature $\times$ Salinity & 4 & 0.40 & 0.58 & $>0.050$ \\
\hline Tank(Temperature $\times$ Salinity) & 9 & 0.69 & 0.84 & $>0.050$ \\
\hline Residual & 558 & 0.82 & & \\
\hline \multicolumn{5}{|l|}{ Salinity } \\
\hline Temperature & 2 & 319 & 73.39 & $\leq 0.001$ \\
\hline Salinity & 2 & 49771 & 11457 & $\leq 0.001$ \\
\hline Temperature $\times$ Salinity & 4 & 15 & 3.41 & $>0.050$ \\
\hline Tank $($ Temperature $\times$ Salinity) & 9 & 4 & 2.19 & $<0.050$ \\
\hline Residual & 558 & 2 & & \\
\hline
\end{tabular}

Table 4. Analysis of variance for the effects of temperature and salinity on $\mathrm{Ba}: \mathrm{Ca}$ and ${ }^{137} \mathrm{Ba}:{ }^{136} \mathrm{Ba}$ ratios in the rearing water and otoliths of Acanthopagrus butcheri

\begin{tabular}{|c|c|c|c|c|}
\hline Source of variation & df & MS & $F$ & $\mathrm{p}$ \\
\hline \multicolumn{5}{|l|}{ Water } \\
\hline \multicolumn{5}{|l|}{ Ba:Ca } \\
\hline Temperature & 2 & 0.004 & 1.180 & $>0.050$ \\
\hline Salinity & 2 & 3.194 & 856.820 & $\leq 0.001$ \\
\hline Temperature $\times$ Salinity & 4 & 0.007 & 1.810 & $>0.050$ \\
\hline Tank(Temperature $\times$ Salinity) & 9 & 0.004 & 0.900 & $>0.050$ \\
\hline Residual & 108 & 0.004 & & \\
\hline \multicolumn{5}{|l|}{${ }^{137} \mathrm{Ba}:{ }^{136} \mathrm{Ba}$} \\
\hline Temperature & 2 & 47 & 4.000 & $<0.050$ \\
\hline Salinity & 2 & 2507 & 233.000 & $\leq 0.001$ \\
\hline Temperature $\times$ Salinity & 4 & 8 & 1.000 & $>0.050$ \\
\hline Tank(Temperature $\times$ Salinity) & 9 & 11 & 1.000 & $>0.050$ \\
\hline Residual & 108 & 13 & & \\
\hline \multicolumn{5}{|l|}{ Otolith } \\
\hline \multicolumn{5}{|l|}{ Ba:Ca } \\
\hline Temperature & 2 & 0.015 & 35.700 & $\leq 0.001$ \\
\hline Salinity & 2 & 0.040 & 91.730 & $\leq 0.001$ \\
\hline Temperature $\times$ Salinity & 4 & 0.002 & 4.890 & $<0.050$ \\
\hline Tank(Temperature $\times$ Salinity) & 9 & 0.000 & 0.380 & $>0.050$ \\
\hline Residual & 102 & 0.001 & & \\
\hline \multicolumn{5}{|l|}{${ }^{137} \mathrm{Ba}:{ }^{166} \mathrm{Ba}$} \\
\hline Temperature & 2 & 10 & 0.240 & $>0.050$ \\
\hline Salinity & 2 & 61 & 1.480 & $>0.050$ \\
\hline Temperature $\times$ Salinity & 4 & 97 & 2.326 & $>0.050$ \\
\hline Tank(Temperature $\times$ Salinity) & 9 & 42 & 3.565 & $\leq 0.001$ \\
\hline Residual & 102 & 11 & & \\
\hline
\end{tabular}

temperature for all 3 salinities, and at ambient temperature and low salinity (Fig. 2).

A significant difference was detected in otolith $\mathrm{Sr}$ : Ca ratios among temperature and salinity treatments (Table 5, Fig. 1b). Post hoc tests indicated that $\mathrm{Sr}$ :Ca differed between low temperature and both the ambient and high temperature treatments. Sr:Ca differed between the highest salinity and both the low and ambient salinity treatments. A significant difference in the otolith ${ }^{88} \mathrm{Sr}:{ }^{86} \mathrm{Sr}$ ratios was detected among tanks (Table 5). Post hoc tests found differences between tanks for 3 treatments (Fig. 2b). A significant interactive Temperature $\times$ Salinity influence was detected (Table 5, Fig. 2b) in otolith ${ }^{88} \mathrm{Sr}:{ }^{86} \mathrm{Sr}$ between low and high salinity treatments at high temperature, where otolith ${ }^{88} \mathrm{Sr}:{ }^{86} \mathrm{Sr}$ ratios decreased with increasing salinity at high temperatures.

\section{Percent contribution of water and diet}

Water contributed from 62 to $84 \%$ of otolith Ba (means calculated per tank). No significant differences in water contributions were detected among salinity or temperature treatments for Ba (Table 6, Fig. 3a). A tank effect was found for 3 treatments (Table 6, Fig. 3a). Water contributed between 59 and $84 \%$ of otolith Sr. Water contributions appeared to increase with increasing salinity except at the high temperature treatment where contributions appeared to decrease with increasing salinity. These differences likely contributed to the significant interaction detected between temperature and salinity (Table 6, Fig. 3b). At low salinity, water contributions differed between the low temperature and both the ambient and high temperatures. In addition, at low temperature, water contributions differed between the low and high salinity, and at the high temperature, differ- 

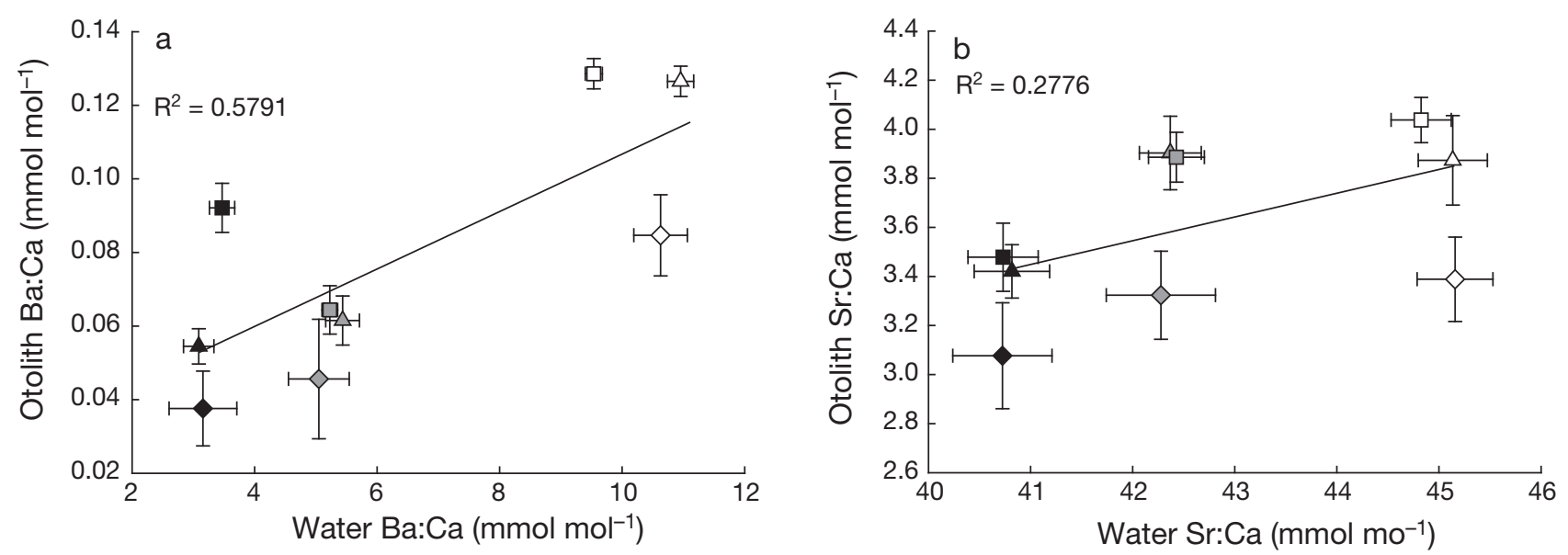

Fig. 1. Mean ( \pm SE) for (a) Ba:Ca and (b) Sr:Ca ratios in the otoliths and rearing water. Symbols represent temperature $(\diamond:$ low; $\boldsymbol{\Delta}$ : ambient; $\mathbf{\square}:$ high), shading represents salinity (white: low; grey: ambient; black: high)

ences were found between the high salinity treatment with both the low and ambient salinity treatments. A significant tank effect was also detected with post hoc tests indicating that there were differences between tanks for 3 treatments (Table 6, Fig. 3b).

Table 5. Analysis of variance for the effects of temperature and salinity on $\mathrm{Sr}: \mathrm{Ca}$ and ${ }^{88} \mathrm{Sr}:{ }^{86} \mathrm{Sr}$ ratios in the rearing water and otoliths of Acanthopagrus butcheri

\begin{tabular}{|c|c|c|c|c|}
\hline Source of variation & $\mathrm{df}$ & MS & $F$ & $\mathrm{p}$ \\
\hline \multicolumn{5}{|l|}{ Water } \\
\hline \multicolumn{5}{|l|}{ Sr:Ca } \\
\hline Temperature & 2 & 0.13 & 0.08 & $>0.050$ \\
\hline Salinity & 2 & 196.60 & 126.33 & $\leq 0.001$ \\
\hline Temperature $\times$ Salinity & 4 & 0.24 & 0.15 & $>0.050$ \\
\hline Tank(Temperature $\times$ Salinity) & 9 & 1.56 & 0.77 & $>0.050$ \\
\hline Residual & 108 & 2.03 & & \\
\hline \multicolumn{5}{|l|}{${ }^{88} \mathrm{Sr}:{ }^{86} \mathrm{Sr}$} \\
\hline Temperature & 2 & 0.02 & 0.38 & $>0.050$ \\
\hline Salinity & 2 & 20.38 & 396.78 & $\leq 0.001$ \\
\hline Temperature $\times$ Salinity & 4 & 0.01 & 0.18 & $>0.050$ \\
\hline Tank(Temperature $\times$ Salinity) & 9 & 0.05 & 0.93 & $>0.050$ \\
\hline Residual & 108 & 0.06 & & \\
\hline \multicolumn{5}{|l|}{ Otolith } \\
\hline \multicolumn{5}{|l|}{ Sr:Ca } \\
\hline Temperature & 2 & 3.18 & 10.42 & $\leq 0.010$ \\
\hline Salinity & 2 & 2.31 & 7.57 & $<0.050$ \\
\hline Temperature $\times$ Salinity & 4 & 0.08 & 0.26 & $>0.050$ \\
\hline Tank(Temperature $\times$ Salinity) & 9 & 0.31 & 0.95 & $>0.050$ \\
\hline Residual & 104 & 0.32 & & \\
\hline \multicolumn{5}{|l|}{${ }^{88} \mathrm{Sr}:{ }^{86} \mathrm{Sr}$} \\
\hline Temperature & 2 & 0.27 & 0.62 & $>0.050$ \\
\hline Salinity & 2 & 3.96 & 8.98 & $<0.050$ \\
\hline Temperature $\times$ Salinity & 4 & 2.08 & 4.71 & $<0.050$ \\
\hline Tank $($ Temperature $\times$ Salinity $)$ & 9 & 0.45 & 4.28 & $\leq 0.001$ \\
\hline Residual & 104 & 0.10 & & \\
\hline
\end{tabular}

\section{DISCUSSION}

Reliable reconstructions of fish environmental history using otolith chemistry can only be achieved if general patterns of elemental uptake in otoliths are known. The present study provides 2 important contributions to reconstructions of fish life history. First, it provides support for past studies which concluded that ambient water is the primary contributor to otolith $\mathrm{Sr}$ and $\mathrm{Ba}$, and that dietary influence on otolith chemistry is secondary but still substantial under certain conditions. Ambient water was the primary contributor to otolith $\mathrm{Sr}$ in Nile tilapia Oreochromis niloticus (Farrell \& Campana 1996) and in rainbow trout Oncorhynchus mykiss (Gibson-Reinemer et al. 2009) and to otolith $\mathrm{Sr}$ and $\mathrm{Ba}$ in mummichogs Fundulus heteroclitus (Walther \& Thorrold 2006). Second, our study provides the first evidence showing that percent contributions from water to otolith $\mathrm{Sr}$ and Ba may vary according to salinity and temperature. All contribution studies to date have tested only 1 temperature and 1 salinity treatment and therefore have been unable to report the effects of both factors. The contributions of diet and water to otolith chemistry could impact migratory reconstructions, especially in regions where high temperatures and high salinities coincide, which may 
Table 6. Analysis of variance comparing the percent contributions from ambient water to otolith $\mathrm{Ba}$ and $\mathrm{Sr}$ among treatments of water temperature, salinity and replicate tanks

\begin{tabular}{|lrrrc|}
\hline Source of variation & df & MS & $F$ & $p$ \\
\hline Ba & & & & \\
Temperature & 2 & 35 & 0.268 & $>0.050$ \\
Salinity & 2 & 374 & 2.853 & $>0.050$ \\
Temperature $\times$ Salinity & 4 & 259 & 1.973 & $>0.050$ \\
Tank(Temperature $\times$ Salinity) & 9 & 132 & 4.233 & $\leq 0.010$ \\
Residual & 102 & 31 & & \\
Sr & & & & \\
Temperature & 2 & 408 & 3.304 & $>0.050$ \\
Salinity & 2 & 291 & 2.354 & $>0.050$ \\
Temperature $\times$ Salinity & 4 & 940 & 7.586 & $\leq 0.010$ \\
Tank(Temperature $\times$ Salinity) & 9 & 125 & 4.212 & $\leq 0.001$ \\
Residual & 104 & 30 & & \\
\hline
\end{tabular}

isotope ratios that differ from the natural isotope ratios.

Barium concentrations in the otoliths of Acanthopagrus butcheri decreased with increasing salinity, following the trend observed in the rearing water, with the exception of the high temperature, high salinity treatment, which had a higher Ba:Ca concentration than the ambient salinity treatment at this temperature. The ${ }^{137} \mathrm{Ba}:{ }^{136} \mathrm{Ba}$ isotope ratio of otoliths displayed a slight increase with salinity, similar to isotope ratio shifts seen in the water. This isotopic shift was more pronounced at the high temperature treatment; however, this was not significant due to the tank effect detected at this temperature. Water contributed between 62 and $84 \%$ of otolith $\mathrm{Ba}$ in this study. No detectable temperature or salinity effects were found for water contributions to otolith $\mathrm{Ba}$. These results suggest that water is the
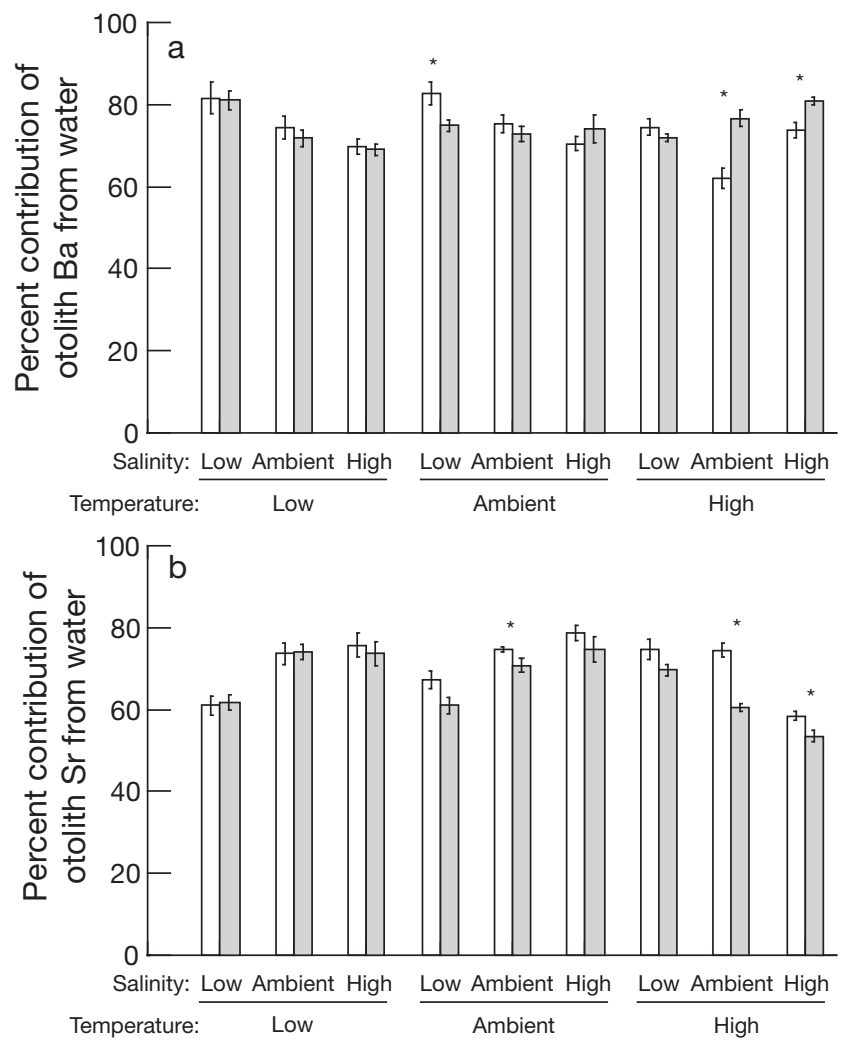

Fig. 3. Mean ( $\pm \mathrm{SE}$ ) percent contribution from the water into the otoliths for (a) Ba and (b) Sr for salinity (low, ambient and high) and temperature (low, ambient and high) treatments. Shading represents replicate tanks (white: Tank 1, grey: Tank 2). Significant differences between replicate tanks are indicated by asterisks 
primary contributor of otolith $\mathrm{Ba}$, and contributions from water and diet to otolith $\mathrm{Ba}$ are similar regardless of water temperature and salinity. This supports previous research that concluded ambient water was the primary contributor to otolith Ba either through studies of Ba:Ca ratios (Buckel et al. 2004, Martin \& Thorrold 2005, Martin \& Wuenschel 2006) or relative contributions of diet and water based on isotope ratios (Walther \& Thorrold 2006). Our estimates are lower than those calculated by Walther \& Thorrold (2006) for a single temperature and salinity, as they reported $98 \%$ of $\mathrm{Ba}$ in juvenile mummichog otoliths was derived from ambient water. This may be due to species-dependent differences and/or the different isotope enrichment levels between water and diet.

The Sr:Ca concentrations in otoliths appeared to increase with temperature and decrease with salinity. The ${ }^{88} \mathrm{Sr}:{ }^{86} \mathrm{Sr}$ isotopic ratio remained relatively consistent, with the exception of the high temperature treatment where the ratio shift decreased with increasing salinity, as seen in the water, despite the tank effects present within the low and ambient salinity treatments at this temperature. Temperature has been found to influence the effects of salinity on the incorporation of $\mathrm{Sr}$, whereby at low temperatures $\left(16^{\circ} \mathrm{C}\right)$ the influence of salinity is reduced, yet at higher temperatures $\left(20\right.$ and $\left.24^{\circ} \mathrm{C}\right)$, strong salinity effects are seen (Elsdon \& Gillanders 2003a). Sr water contributions were affected by an interaction between temperature and salinity, where contributions from water decreased with increasing salinity at the high temperature treatment. This could be due to 2 possible reasons: (1) the contribution at the high temperature is reflective of the difference in the isotope ratios at the high temperature treatment in the otoliths, or (2) given that contribution from diet is $100 \%$ minus the percent contribution from water, the decrease in water contribution suggests that the contribution from diet increased with increasing salinity at high temperature. As water contributed between 59 and $84 \%$ of otolith Sr for all treatments, the results imply that water is, in general, the primary contributor of Sr to otoliths in Acanthopagrus butcheri. Water has also been reported as the primary contributor of Sr isotopes to otoliths in other studies (Farrell \& Campana 1996, Walther \& Thorrold 2006, Gibson-Reinemer et al. 2009). Our estimates are consistent with those reported in previous studies. Farrell \& Campana (1996) suggested that $88 \%$ of otolith $\mathrm{Sr}$ was water-derived in Nile tilapia, Walther \& Thorrold (2006) suggested $83 \%$ in mummichogs, and GibsonReinemer et al. (2009) suggested $66 \%$ in rainbow trout. The differences in water estimates may be due to species-specific differences or the different treatments used.

Changes in elemental composition within the otoliths due to temperature may be a result of kinetics. Changes in proteins surrounding the otolith are thought to be due to kinetic effects (Kalish 1989, Elsdon \& Gillanders 2002). The activity of these proteins is likely to be affected by temperature and may affect the morphology of the otolith crystal. Changes in the morphology of the otolith have been shown to affect the uptake of elements (Brown \& Severin 1999). The results suggest that the otolith crystal may have been compromised at high temperature, and thus $\mathrm{Ba}$ and Sr may have been more readily incorporated into the otolith at the high temperature and high salinity treatment, similar to findings by Elsdon \& Gillanders $(2002,2003 a)$. Other studies that investigated temperature and salinity effects on otolith $\mathrm{Ba}$ :Ca ratios found no significant temperature-salinity interactions (Martin \& Thorrold 2005, Martin \& Wuenschel 2006). Discrepancies among the various kineticfocused calcifying models have yet to be fully resolved experimentally, but the potential for physiochemical control on otolith chemical composition is significant (Walther et al. 2010).

Food intake in fish has been shown to increase with both increasing salinity (Rubio et al. 2005) and temperature (e.g. Boeuf \& Payan 2001, Handeland et al. 2008, Arjona et al. 2009). The decrease in otolith Sr ratios across salinity treatments only occurred at high temperatures. As high temperatures may enhance salinity effects (Elsdon \& Gillanders 2002), food intake may have been further increased through the cumulative effects of salinity and temperature, thus leading to the pattern seen among otolith ${ }^{88} \mathrm{Sr}:{ }^{86} \mathrm{Sr}$ ratios at high temperature treatments. Therefore, the increased food intake would have limited the shift in ${ }^{88} \mathrm{Sr}:{ }^{86} \mathrm{Sr}$ ratios caused by the water.

This is the first study which altered the isotope ratios of both water and diet to determine the percent contribution of elemental intake into the calcifying structure of the otolith. Variations in the isotope ratios in otoliths were similar to those displayed in the water, leading to ambiguity in contribution from the diet, which had a consistent ratio. Further work is required to look at rates of change in isotope ratios given the spiking concentration and which isotope is enriched, and to determine whether these different rates of change are equally reflected in otoliths. Although not addressed in this study, it may be important to determine independent differences of an enriched isotope diet on otolith composition. 
Acknowledgements. We thank A. Netting, B. Wade and A. McFadden (Adelaide Microscopy, University of Adelaide) for assistance with water, diet and otolith analysis and T. Elsdon and A. Munro for comments on experimental design and data analysis. The project was funded by an ARC Discovery Grant and an ARC Future Fellowship to B.M.G. All research was approved by the University of Adelaide Animal Ethics Committee (S-2010-033).

\section{LITERATURE CITED}

Arai T, Sato H, Ishii T, Tsukamoto K (2003) Alkaline earth metal and Mn distribution in otoliths of Anguilla spp. glass eels and elvers. Fish Sci 69:421-423

Arai T, Kotake A, Lokman PM, Miller MJ, Tsukamoto K (2004) Evidence of different habitat use by New Zealand freshwater eels Anguilla australis and A. dieffenbachii, as revealed by otolith microchemistry. Mar Ecol Prog Ser 266:213-225

Arjona FJ, Vargas-Chacoff L, Ruiz-Jarabo I, Goncalves O, Pascoa I, del Rio MPM, Mancera JM (2009) Tertiary stress responses in Senegalese sole (Solea senegalensis Kaup, 1858) to osmotic challenge: implications for osmoregulation, energy metabolism and growth. Aquaculture 287:419-426

> Bath GE, Thorrold SR, Jones CM, Campana SE, McLaren JW, Lam JWH (2000) Strontium and barium uptake in aragonitic otoliths of marine fish. Geochim Cosmochim Acta 64:1705-1714

> Bergenius MAJ, Mapstone BD, Begg GA, Murchie CD (2005) The use of otolith chemistry to determine stock structure of three epinepheline serranid coral reef fishes on the Great Barrier Reef, Australia. Fish Res 72:253-270

Boeuf G, Payan P (2001) How should salinity influence fish growth? Comp Biochem Physiol C Toxicol Pharmacol 130:411-423

Brown R, Severin KP (1999) Elemental distribution within polymorphic inconnu (Stenodus leucichthys) otoliths is affected by crystal structure. Can J Fish Aquat Sci 56: 1898-1903

> Buckel JA, Sharack BL, Zdanowicz VS (2004) Effect of diet on otolith composition in Pomatomus saltatrix, an estuarine piscivore. J Fish Biol 64:1469-1484

Campana SE (1999) Chemistry and composition of fish otoliths: pathways, mechanisms and applications. Mar Ecol Prog Ser 188:263-297

> Campana SE, Neilson JD (1985) Microstructure of fish otoliths. Can J Fish Aquat Sci 42:1014-1032

> Campana SE, Thorrold SR (2001) Otoliths, increments, and elements: keys to a comprehensive understanding of fish populations? Can J Fish Aquat Sci 58:30-38

> Crook DA, O'Mahony DJ, Sanger AC, Munro AR, Gillanders BM, Thurstan S (2009) Development and evaluation of methods for osmotic induction marking of golden perch Macquaria ambigua with calcein and alizarin Red S. N Am J Fish Manag 29:279-287

de Vries MC, Gillanders BM, Elsdon TS (2005) Facilitation of barium uptake into fish otoliths: influence of strontium concentration and salinity. Geochim Cosmochim Acta 69: 4061-4072

Elsdon TS, Gillanders BM (2002) Interactive effects of temperature and salinity on otolith chemistry: challenges for determining environmental histories of fish. Can J Fish Aquat Sci 59:1796-1808
Elsdon TS, Gillanders BM (2003a) Reconstructing migratory patterns of fish based on environmental influences on otolith chemistry. Rev Fish Biol Fish 13:217-235

Elsdon TS, Gillanders BM (2003b) Relationship between water and otolith elemental concentrations in juvenile black bream Acanthopagrus butcheri. Mar Ecol Prog Ser 260:263-272

> Elsdon TS, Gillanders BM (2006) Identifying migratory contingents of fish by combining otolith Sr:Ca with temporal collections of ambient Sr:Ca concentrations. J Fish Biol 69:643-657

> Elsdon TS, Wells BK, Campana SE, Gillanders BM and others (2008) Otolith chemistry to describe movements and life-history parameters of fishes: hypotheses, assumptions, limitations and inferences. Oceanogr Mar Biol Annu Rev 46:297-330

Farrell J, Campana SE (1996) Regulation of calcium and strontium deposition on the otoliths of juvenile tilapia, Oreochromis niloticus. Comp Biochem Physiol A Physiol 115:103-109

Gibson-Reinemer DK, Johnson BM, Martinez PJ, Winkelman DL, Koenig AE, Woodhead JD (2009) Elemental signatures in otoliths of hatchery rainbow trout (Oncorhynchus mykiss): distinctiveness and utility for detecting origins and movement. Can J Fish Aquat Sci 66: 513-524

Gillanders BM (2005) Otolith chemistry to determine movements of diadromous and freshwater fish. Aquat Living Resour 18:291-300

> Handeland SO, Imsland AK, Stefansson SO (2008) The effect of temperature and fish size on growth, feed intake, food conversion efficiency and stomach evacuation rate of Atlantic salmon post-smolts. Aquaculture 283:36-42

Imsland AK, Foss A, Gunnarsson S, Berntssen MHG and others (2001) The interaction of temperature and salinity on growth and food conversion in juvenile turbot (Scophthalmus maximus). Aquaculture 198:353-367

Jónsdóttir IG, Campana SE, Marteinsdottir G (2006) Stock structure of Icelandic cod Gadus morhua L. based on otolith chemistry. J Fish Biol 69:136-150

Kalish JM (1989) Otolith microchemistry - validation of the effects of physiology, age and environment on otolith composition. J Exp Mar Biol Ecol 132:151-178

Kennedy BP, Blum JD, Folt CL, Nislow KH (2000) Using natural strontium isotopic signatures as fish markers: methodology and application. Can J Fish Aquat Sci 57: 2280-2292

Kraus RT, Secor DH (2004) Incorporation of strontium into otoliths of an estuarine fish. J Exp Mar Biol Ecol 302: 85-106

Lignot JH, Spanings-Pierrot C, Charmantier G (2000) Osmoregulatory capacity as a tool in monitoring the physiological condition and the effect of stress in crustaceans. Aquaculture 191:209-245

> Luz RK, Martinez-Alvarez RM, De Pedro N, Delgado MJ (2008) Growth, food intake regulation and metabolic adaptations in goldfish (Carassius auratus) exposed to different salinities. Aquaculture 276:171-178

> Martin GB, Thorrold SR (2005) Temperature and salinity effects on magnesium, manganese, and barium incorporation in otoliths of larval and early juvenile spot Leiostomus xanthurus. Mar Ecol Prog Ser 293:223-232

Martin GB, Wuenschel MJ (2006) Effect of temperature and salinity on otolith element incorporation in juvenile gray 
snapper Lutjanus griseus. Mar Ecol Prog Ser 324: 229-239

Munro AR, Gillanders BM, Elsdon TS, Crook DA, Sanger AC (2008) Enriched stable isotope marking of juvenile golden perch (Macquaria ambigua) otoliths. Can J Fish Aquat Sci 65:276-285

Perry SF (1997) The chloride cell: structure and function in the gills of freshwater fishes. Annu Rev Physiol 59: 325-347

Potter IC, Beckley LE, Whitfield AK, Lenanton RCJ (1990) Comparisons between the roles played by estuaries in the life cycles of fishes in temperate Western Australia and Southern Africa. Environ Biol Fishes 28:143-178

Royes JB, Chapman FA (2003) Preparing your own fish feeds. Circular No. 97. Extension. Institute of Food and Agricultural Sciences, University of Florida, Gainesville, FL

Rubio VC, Sanchez-Vazquez FJ, Madrid JA (2005) Effects of salinity on food intake and macronutrient selection in European sea bass. Physiol Behav 85:333-339

Editorial responsibility: Stylianos Somarakis, Heraklion, Greece
Sadovy Y, Severin KP (1994) Elemental patterns in red hind (Epinephelus guttatus) otoliths from Bermuda and Puerto Rico reflect growth rate, not temperature. Can J Fish Aquat Sci 51:133-141

Swanson C (1998) Interactive effects of salinity on metabolic rate, activity, growth and osmoregulation in the euryhaline milkfish (Chanos chanos). J Exp Biol 201: 3355-3366

> Walther BD, Thorrold SR (2006) Water, not food, contributes the majority of strontium and barium deposited in the otoliths of a marine fish. Mar Ecol Prog Ser 311: $125-130$

Walther B, Kingsford M, O'Callaghan M, McCulloch M (2010) Interactive effects of ontogeny, food ration and temperature on elemental incorporation in otoliths of a coral reef fish. Environ Biol Fishes 89:441-451

$>$ Woodcock SH, Gillanders BM, Munro AR, Crook DA, Sanger AC (2011) Determining mark success of 15 combinations of enriched stable isotopes for the batch marking of larval otoliths. N Am J Fish Manag 31:843-851

Submitted: September 14, 2011; Accepted: February 6, 2012 Proofs received from author(s): April 5, 2012 